\title{
Geochemical mapping and environmental indexing of an urban area (Rio Grande, RS)
}

\author{
Nicolai Mirlean* \\ Mariana Luzia Ribeiro Gripp \\ Federal University of Rio Grande \\ Oceanography Institute \\ Rio Grande-RS, Brazil \\ Campus Carreiros \\ Av. Italia km 08 \\ Rio Grande RS Brazil \\ CEP 96203-900 \\ * corresponding author \\ dgeonmir@furg.br \\ +55 53 32336786;
}

\begin{abstract}
RESUMO
Realizamos um mapeamento geoquímico da cobertura de solo dos setores industriais e residenciais da cidade de Rio Grande (RS). Várias zonas anômalas de mercúrio, cobre, zinco, chumbo, níquel, cromo e ferro foram identificadas, o que correspondeu à alocação histórico-espacial de diferentes indústrias da cidade. O mapeamento do território da cidade usando o complexo índice eco-geoquímico Zc demonstrou que a maior parte da área urbana está contaminada com metais até o nível que requer medidas de mitigação obrigatórias. A aplicação do método de subtração sequencial a partir do complexo índice de elementos pelo grau de sua participação na contaminação do território possibilitou estabelecer uma associação paragenética de metais $\mathrm{Cu}, \mathrm{Pb}, \mathrm{Zn}$, que formam os centros de contaminação por metais na cidade. Com base nos dados recebidos, uma avaliação da poluição da área urbana foi realizada de acordo com a legislação brasileira. A avaliação da área amostrada segundo a legislação referida enquadra o solo estudado como pertencente à Classe 4, ou seja, a área necessita de gerenciamento imediato, que incluem eliminação dos riscos à saúde humana e ao meio ambiente e planejamento dos usos futuros do solo.

Palavras-Chave: mapeamento geoquímico, cobertura de solo, metais, áreas urbanas
\end{abstract}

\begin{abstract}
We have carried out a geochemical mapping of soil cover of industrial and residential sectors of the city of Rio Grande (RS). Various anomalous zones of mercury, copper, zinc, lead, nickel, chromium and iron have been identified, which corresponded to the historic-spatial allocation of different industries in the city. The mapping of the city's territory using the complex eco-geochemical index $\mathrm{Zc}$ demonstrated that most of the urban area is contaminated with metals up to the level requiring mandatory mitigation measures. The application of the method of sequential subtraction from the complex index of elements by the degree of their participation in the contamination of the territory made it possible to establish a paragenetic association of metals $\mathrm{Cu}, \mathrm{Pb}, \mathrm{Zn}$, which forms the centers of metal contamination in the city. Based on the data received, an assessment of the pollution of the urban area was carried out in accordance with Brazilian legislation. This evaluation testified that studied soil belongs to Class 4 according to legislative norms, which means that the city needs immediate environmental management in terms of eliminating risks to human health and the environmental planning of future land use.
\end{abstract}

Keywords: geochemical mapping, soil cover,metals, urban areas

\section{INTRODUCTION}

The importance of metals in human activities causes the release of large quantities into the environment, both as waste from production and from disposal, by changing the natural concentrations of these elements in the various compartments, such as soils, sediments, groundwater and atmosphere. Heavy metals have a long residence time; they are not biodegradable, i.e. they are not modified or degraded like organic contaminants accumulating in the trophic chain. 
Metals are considered toxic when in high concentrations, even those which are essential for organisms. Therefore, the total concentration of heavy metals in the soil can be used as an indicator of environmental quality.

Contamination of urban soils by chemical elements and their compounds has been recognized as one of the major concerns at the local, regional and global level due to the implications for human health (Alloway 1990; Kabata-Pendias and Pendias 1992; De Kimpe and Morel 2000). Among the sources of pollution of urban soils are: industrial effluents, domestic effluents, constructions, because of debris, paint and weathering of buildings; transportation, pollution emitted by vehicles such as combustion wastes from the engines, particles emitted by the tires and resuspension of a dust from highways; exploitation and processing of raw material - e.g. metallurgical and mining industry; (ATSDR, 1999, 2004, 2005; Lu \& Bai, 2010).

The importance of geochemistry, especially urban geochemistry, is demonstrated by the large number of publications mainly in recent decades. Among them, it should be mentioned the ones that investigate the composition of metals in urban parks, in industrial areas, as well as those that compare less impacted regions, such as rural areas, with urbanized regions (Li et al. 2001; Chen et al. 2005; Madrid et al. 2002; MortonBermea et al. 2010; Jagtap et al. 2010; Kelly \& Thorton 1996; Krishna \& Govil, 2004; Krishna \& Govil, 2005; Krishna \& Govil, 2008; Li \& Huang, 2007; Romic \& Romic, 2003.) However, the majority of these studies, have not the unified system approach which takes into account the complex impact of polymetallic pollution on the urban environment. In the middle of the 1970s a new research area "geochemistry of cities" was

\section{MATERIALS AND METHODS}

Located in a coastal region of southern Brazil, the city of Rio Grande occupies a sheltered peninsula near the mouth of the estuarine system of Laguna dos Patos (Fig. 1). This territory is characterized by an extensive coastal plain of strictly sedimentary geological formation, unfavorable to the formation of well developed soils (Bastos et al., 2005). rapidly developed in the USSR. It was based on the fundamental premise that the industrial-urban complexes in their nature and mode of metals distribution resemble the weathering ore deposits (Saet 1990). This allowed to development of a methodology for the complex geochemical survey of urban areas. The method included, in addition to the mandatory mapping of soil and snow cover, also an environmental assessment based on newly proposed indices. Special methods were used to identify the centers of pollution and the direction of their development in the urban settings. By this method, large administrative and industrial centers of the country were geochemically studied. Based on the geochemical research results, the definite decisions were taken to reduce the negative impact of pollution on the population and also were adjusted the urban development plans were adjusted. Our personal previous experience on geochemical mapping of cities was based on a full geochemical study of the territory of the capital of Moldova, Kishinev (Mirlean et al. 1992).

In Brazil, the first regulation of the National Council on the Environment (CONAMA) on the contaminant residues of soil has appeared in 2002 and deals with the final disposal of urban solid waste. More recently CONAMA Resolution No. 420 of 2009 was promulgated, providing criteria and guiding values of soil quality for the presence of chemical substances (CONAMA, 20019).

In this article, we present the results of the first geochemical mapping and ecological assessment carried out in Brazil in the city of Rio Grande using the ideas and methods of geochemical studies of cities developed in the USSR (Saet 1990). We also used Brazilian environmental regulation norms for the ecological assessment of the studied area.

The original sedimentary cover of the city of Rio Grande before urbanization was formed by fields of dunes, wetlands and floodplain (Bastos et al., 2002). According to the generalized geological and pedological maps the sampled area is the geotechnical unit of plains and dunes, formed by hydromorphic quartz sands with the substrate composed of beach marine and Pleistocene eolic deposits (Bastos et al., 2005). 


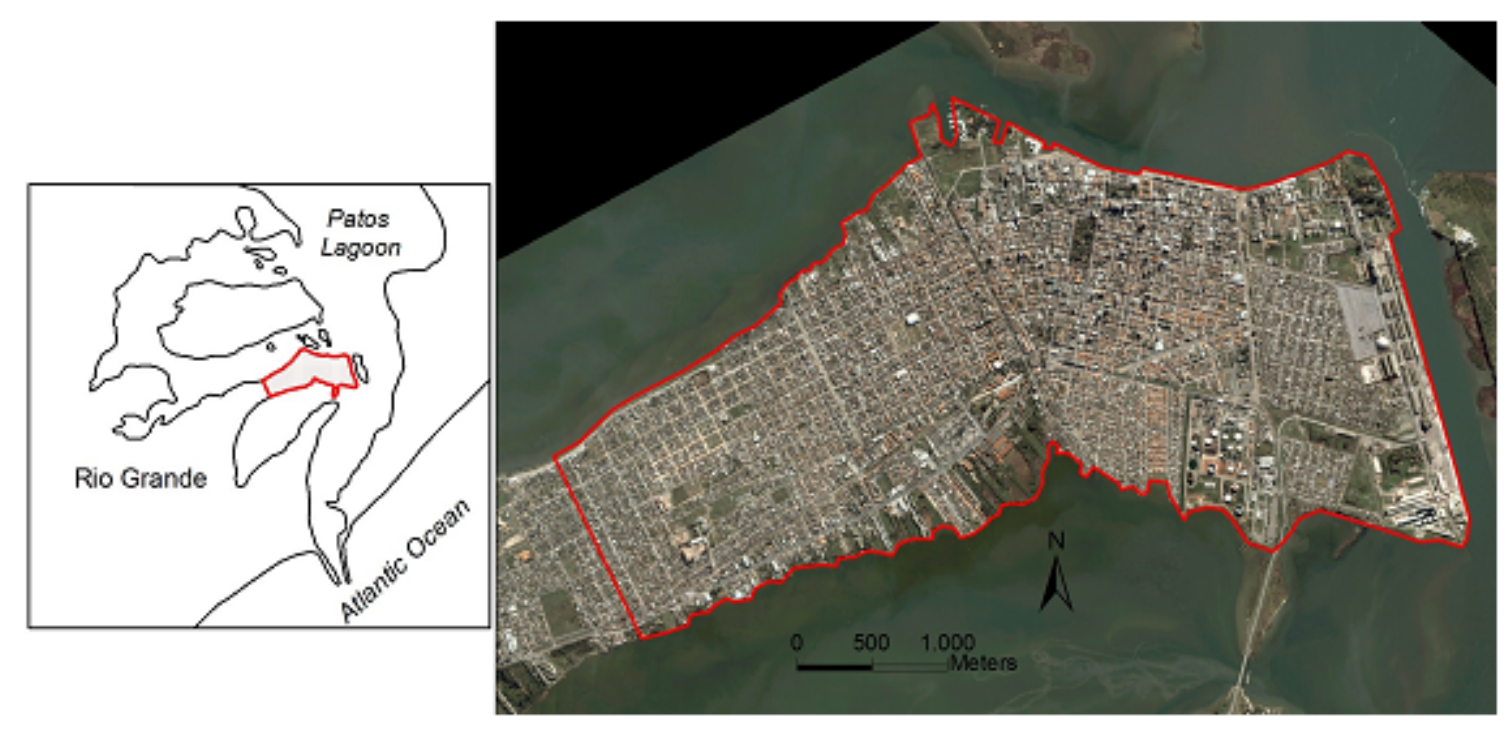

Figure 1

The area sampled in the city of Rio Grande.

Rio Grande is the oldest city in the state of Rio Grande do Sul and the only marine port,which provided its development since the nineteenth century, with significantly growing industrial park. Martins (2006) recalls that the installation of industries is not limited to the appearance of industrial plants, but "a whole set of elements and factors that will mark this kind of production". The author has segmented historical spatialization of the city of Rio Grande into several phases. The approximate division was used in this work (Figure 2), in order to understand the differences in the land uses according to the predominant activities, since the commercial activities and industries, besides the type of urbanization, are the keys to the understanding of the types of pollution:

- from 1730 to 1874: commercial period, when the activities were limited to the Historical Center;

- from 1874 to 1910: dispersed industrialization, when the city suffered its first urban expansion (formation of the "Bairro Cidade Nova" from 1890);

- from 1910 to 1970 , the extensive land works marked this period, as the New Landfill (Western Embankment), the installation of the Refinery, the fishery industry and the expansion of villages to the west;

- from 1970, development of the Industrial District and the Super Port, industries of fertilizers and the growth of the fishing industry. However, the expansion area of this period was out of our sampling area: as it does not contain significant dwelling blocks.

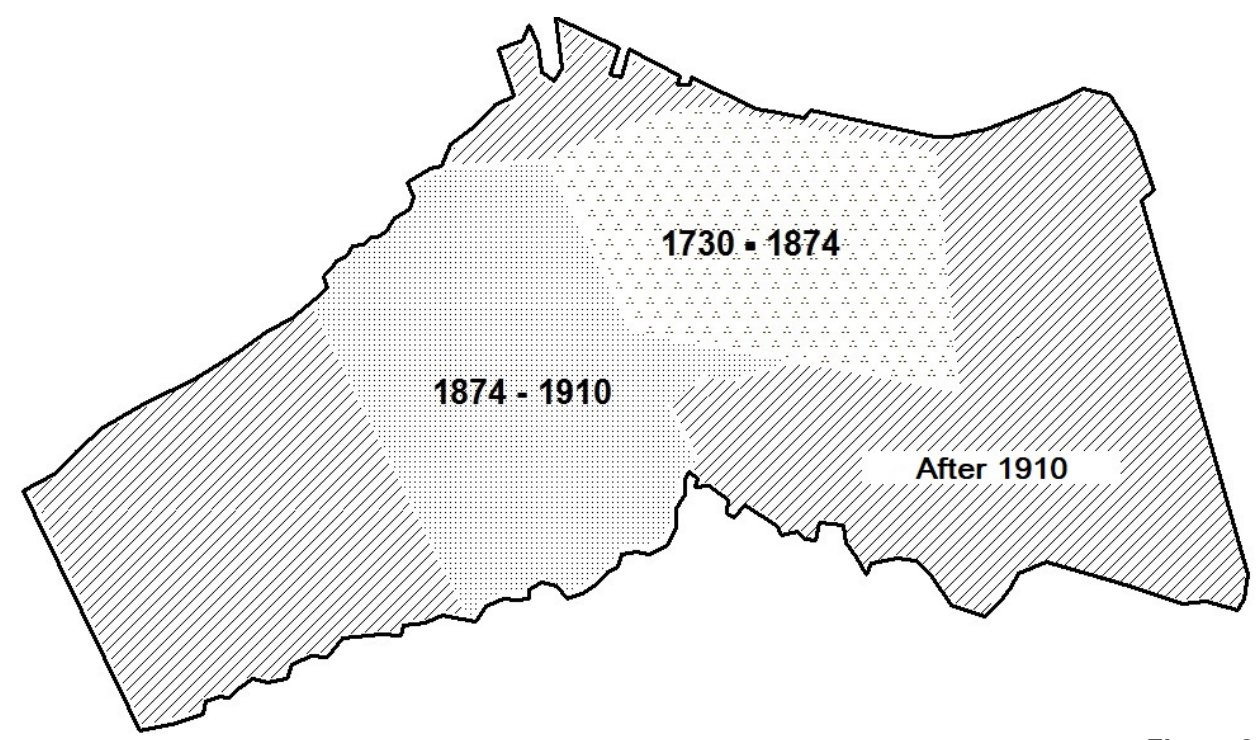

Figure 2

Occupancy of the sampled area in the city of Rio Grande according to Martins (2006). 
Soil samples were collected along transects oriented by streets, covering the most urbanindustrial part of the city of Rio Grande and totaling 203 samples (Fig. 3). Samples were collected with a plastic sampler to a depth of 10 $\mathrm{cm}$. The sampling was performed between August
2004 and August 2005. The soil samples (100 g) were stored in plastic bags and transported to the laboratory. A GPS device (GPSMAP ${ }^{\circledR}$ 60CSx) was used for the spatial location of the points sampled.

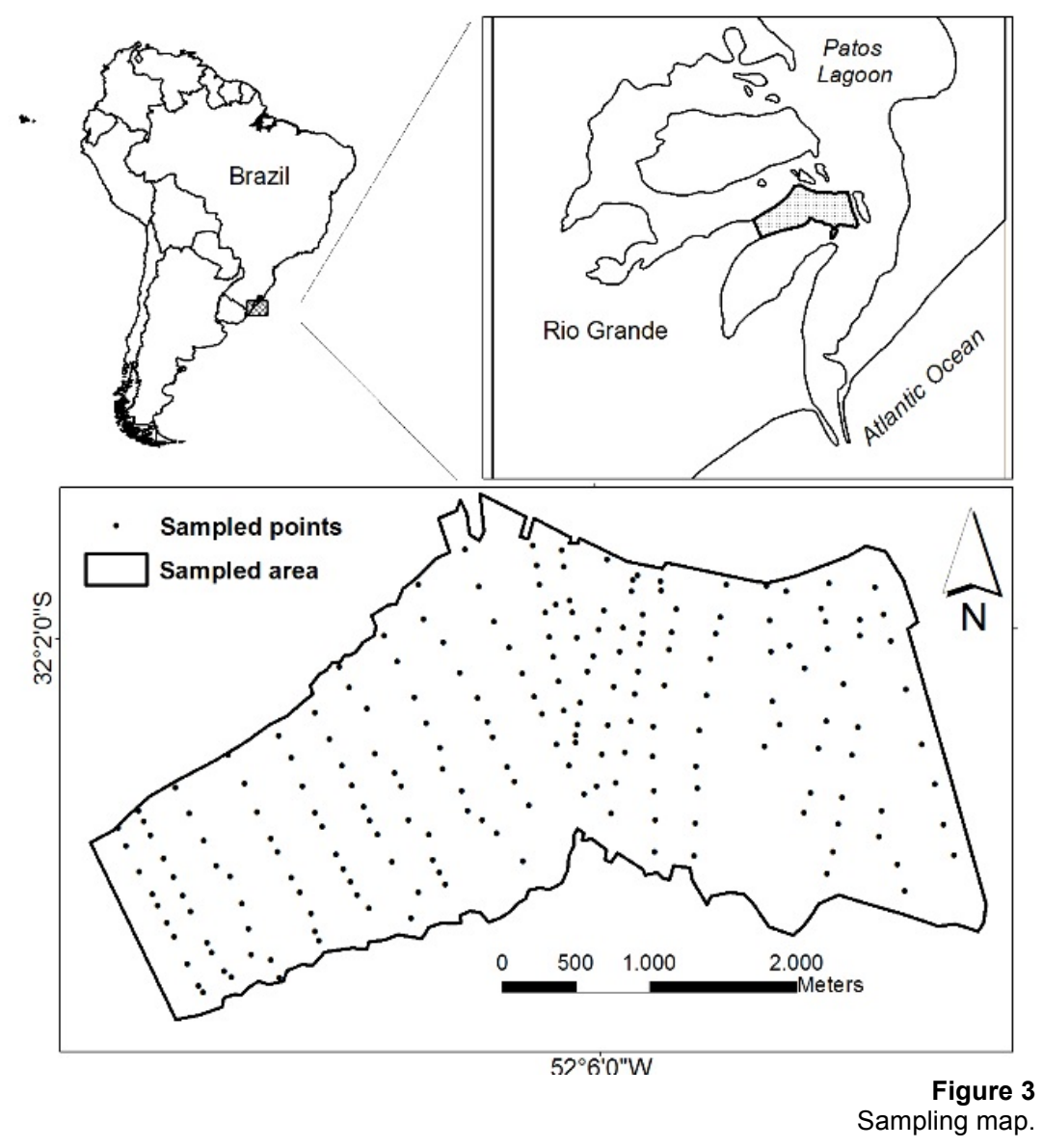

Determination of background spectrum and concentration thresholds were determined in accordance with the experience of other investigators (Reimannet et al., 2005; Grünfeld, 2005,Anderson \& Kravitz, 2010). For the determination of the local background the soil samples were collected in an urbanized area of the city, which remained without direct visual anthropogenic interference. This area was located on the site of the Federal University of Rio Grande - FURG.

For the $\mathrm{Pb}, \mathrm{Cu}, \mathrm{Zn}, \mathrm{Cr}, \mathrm{Ni}$ and $\mathrm{Fe}$ analyses, the samples were dried at room temperature, sieved in $100 \mu \mathrm{m}$ sieves, and pulverized in mortar of agate. Approximately one gram of each sample of the pulverized material was digested in $5 \mathrm{~mL}$ of aqua regia ( $\mathrm{HCl}: \mathrm{HNO} 3: 1)$ for 12 hours and placed in thermostatic bath for 2 hours at $60^{\circ} \mathrm{C}$. After this procedure the solutions were filtered and the volume was completed with distilled water to 50 $\mathrm{mL}$.

$\mathrm{Hg}$ values were measured using the cold steam system coupled to Atomic Absorption Spectrophotometer (GBC 932AA). Each sample was analyzed three times and the mean values were calculated. The maximum values of the standard deviations of the individual samples were less than $4 \%$. The accuracy of the analyzes was supported by sequential digestion and analysis of reference material PACS-2 and MESS-3 (National Research Council of Canada). The results obtained from the analyzes are in agreement with the certificates $( \pm 5 \%)$. 


\section{RESULTS AND DISCUSSION}

In soils of the city of Rio Grande, the following average contents of the investigated elements were found in $\mathrm{mg} / \mathrm{kg}$ (in parentheses the excess over the local background is given): $\mathrm{Hg}$ $=0.44$ (16.7), Pb-207.1 (129.4), Zn-367.6 (193.5), $\mathrm{Cu}-273.7$ (304.1), Cr-206.2 (108.5), Ni-5.4 (5.4), Fe-12482 (8.7). Thus, the soil of the city shows a high level of enrichment in all the elements studied.

The following maps of metal isoconcentrations in the surface horizon of the soil gave a rather detailed picture of their distribution, reflecting history of the use of metals in the domestic and industrial activity in the city (Figure 4).

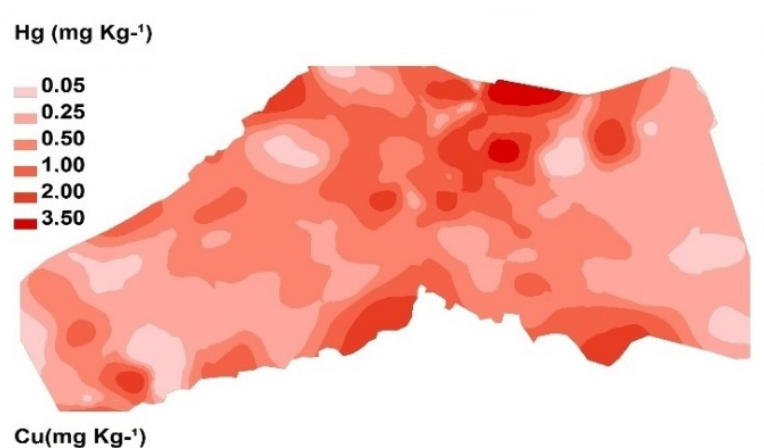

$\mathrm{Pb}\left(\mathbf{m g ~ K g - 1}^{-1}\right)$
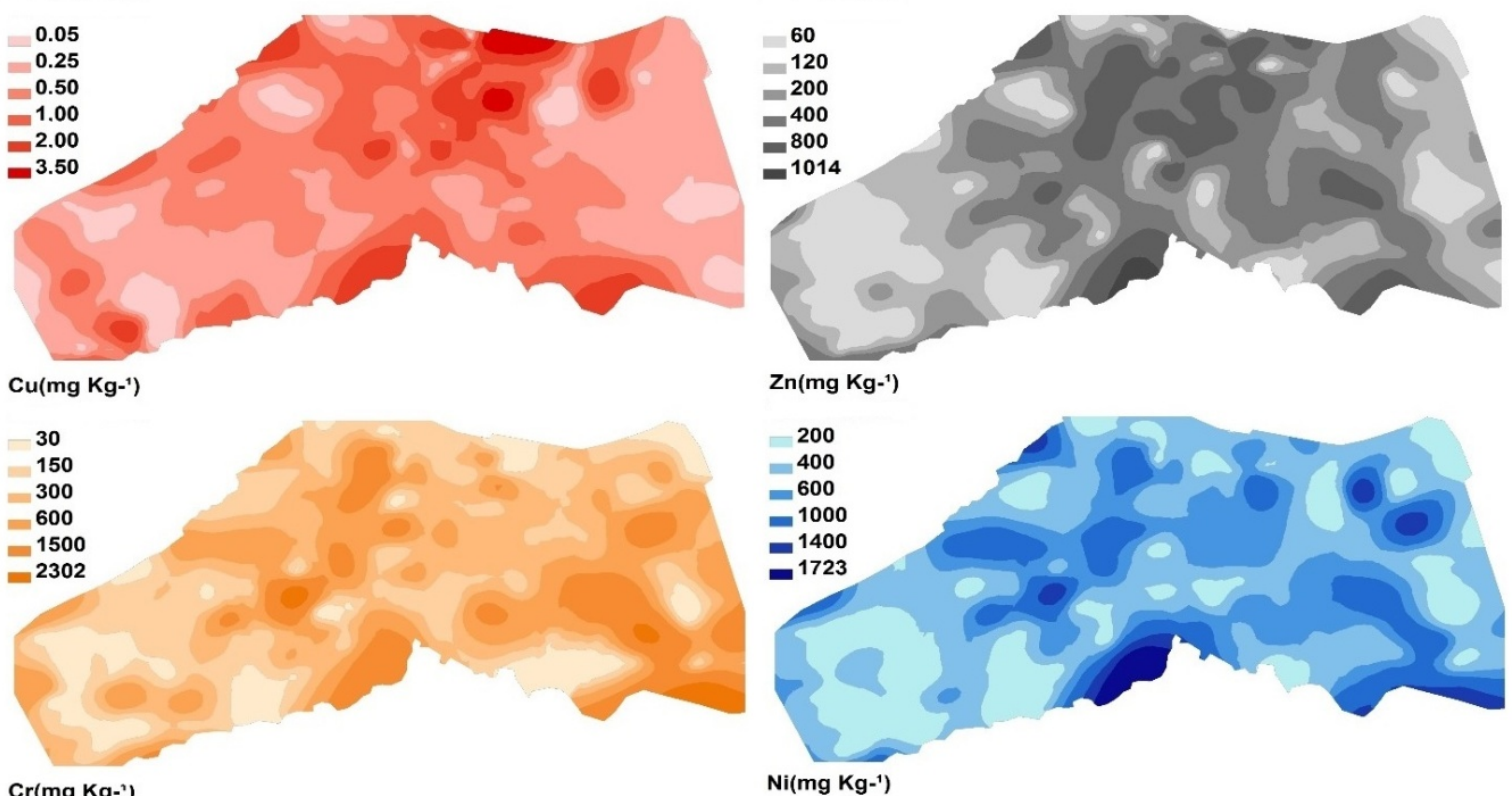

Cr(mg Kg-')
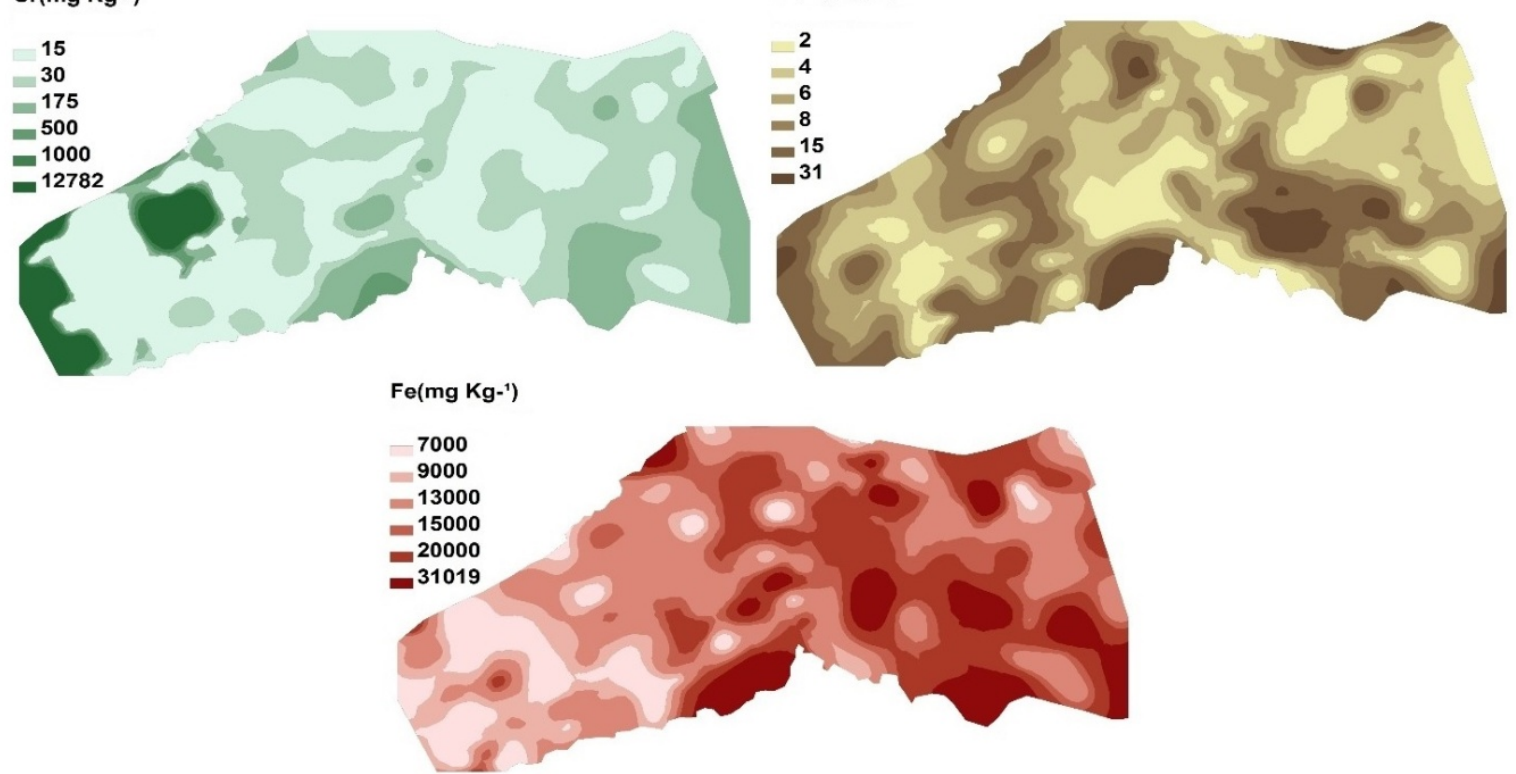

Figure 4

Distribution of $\mathrm{Hg}, \mathrm{Cu}, \mathrm{Pb}, \mathrm{Zn}, \mathrm{Ni}, \mathrm{Cr}$ and $\mathrm{Fe}$ in surface soil according to Gripp, (2012).

The concentration of $\mathrm{Hg}$ in soil cover ranged from 0.02 to $3.5 \mathrm{mg} \mathrm{kg}^{-1}$, i.e. its highest content was 140 times higher than the lowest one. Several anomalous centers of this metal, configured by concentrations contorted by gradually lower contents, exhibiting a dispersion pattern may be observed on the map. The large anomalies in the central region of the city (Historical Center) were 
represented by concentrations greater than $2 \mathrm{mg}$ $\mathrm{kg}^{-1}$, reaching $3.5 \mathrm{mg} \mathrm{kg}^{-1}$.

The history of $\mathrm{Hg}$ contamination in the city spans over than 250 years. In our previous studies, we demonstrated that soil $\mathrm{Hg}$ contamination in Rio Grande began almost simultaneously with the foundation of the city (Oliveira and Mirlean, 2006). We believe that such early mercury contamination was related to the process of carrotting used for processing animal skins with nitrate of mercury, which was an innovation in the 18th century and continued to be used in Brazil until the mid-20th century. The central part of the city, which is the most polluted by $\mathrm{Hg}$, corresponds to the Old City area in the 18th century, where handicraft production was performed without centralized utilization of $\mathrm{Hg}$ residues, which were simply discarded out onto the streets. Other anomalies of mercury in the city are associated primarily with the dislocation of soil material from the old city center (together with construction debris) to the peripheral areas and the use of these materials for man-made lands in the shallow water coastal area of the Patos estuary. The anomalies of $\mathrm{Hg}$ in the southern part of the city corresponded to the former municipal landfills, where the street garbage contaminated with $\mathrm{Hg}$ was also deposited.

The concentration of $\mathrm{Pb}$ in soil cover varied from 3.86 to $1014.3 \mathrm{mg} \mathrm{kg}^{-1}$ and the ones displayed on the map in ranges from 60 to $400 \mathrm{mg}$ $\mathrm{kg}^{-1}$. Most of the anomalies were detected in the central part of the city at historical districts. In our previous publications, we demonstrated that there are three main sources of lead pollution in the city: i)handicraft production of lead for fishingtakle; ii) lead elements in local architecture; and the most important is iii) the paints of building facades (Mirlean et al 2005). Anomalies of lead in the soil of the central part of the city are most likely associated with the peeling of the colorful coating of facades of historic buildings. Anomalies in the southern part of the city correspond to the sites of old urban dumpsites. The relatively reduced amount of lead in the western city's squares was the result of mineral lead-containing paints change to new polymeric paints in the younger city areas.

The $\mathrm{Zn}$ concentration in studied soil varied from 23.9 to $1723.2 \mathrm{mg} \mathrm{kg}^{-1}$. The intervals used in the mapping ranged from 200 to $400 \mathrm{mg} \mathrm{kg}{ }^{-1}$ and were sufficient to generate clear visualization of metal distribution, with centers up to $1400 \mathrm{mg}$ $\mathrm{kg}^{-1}$; as well as 'cleaner' regions in the new part of the city, where $\mathrm{Zn}$ concentration was below 400 $\mathrm{mg} \mathrm{kg}^{-1}$ in most of the area.
The $\mathrm{Zn}$ presented a distribution different from $\mathrm{Hg}$ and $\mathrm{Pb}$ ones; the region of the Historical Center presents lower levels of $\mathrm{Zn}$ contamination when compared with the most distinct parts of the city. Location of the main zinc anomalies in more young squares of the city, which were populated already in the 20th century, illustrates the changing priorities and volumes of use of metals in the industrial and residential sectors. Zinc as a metal was massively used after the development of electroplated steel in the first third of the 20th century, especially in the form of galvanized roof coverings. This period includes the development of zinc-enriched soils of the city's districts, as well as port and industrial areas in the east and southeast of the city.

The concentration of $\mathrm{Cu}$ the soil varied from 0.7 to $2302 \mathrm{mg} \mathrm{kg}^{-1}$. In general $\mathrm{Cu}$ demonstrated Zn-like distribution of concentrations, whose anomalies for high values are close to district of Cidade Nova . The region of the Historical Center and the younger portion of the city (west of the map) demonstrated the lowest $\mathrm{Cu}$ concentrations soil, not more than $300 \mathrm{mg} \mathrm{kg}^{-1}$ and $150 \mathrm{mg} \mathrm{kg}^{-1}$ respectively (Fig. 4).

This character of the distribution of $\mathrm{Cu}$ in the urban soils is associated with the same process of changing in the associations of metals involved into industrial and household activities in the historical process of city development. In addition, $\mathrm{Cu}$ and $\mathrm{Zn}$, together with $\mathrm{Pb}$, constitute an obligatory paragenetic association of metals in the pollution spectrum of almost all large settlements in the world (Saet, 1990).

$\mathrm{Cr}$ presents very peculiar distribution in the soil of Rio Grande. Its concentration varies from 0.1 to $12782 \mathrm{mg} \mathrm{kg}^{-1}$, but only in the newest part of the city (west of the Cidade Nova) were found the highest $\mathrm{Cr}$ levels in the centers of the anomalies. In the rest of the city, the concentration of the metal did not exceed $175 \mathrm{mg} \mathrm{kg}^{-1}$, and most of them were below $30 \mathrm{mg} \mathrm{kg}^{-1}$, except for the region near the urban waste dump- $500 \mathrm{mg} \mathrm{kg}^{-1}$. This very contrasting distribution of chromium in the soil of the city is a consequence of two factors. The first factor is historical, $\mathrm{Cr}$ later than other metals appeared in the spectrum of metals involved in the local industries and household processes. The second factor is the specificity of using this metal in the city, the main quantity of chromium is present in the automotive parts. Therefore, the main chromium anomalies in the soils of the city were found in its youngest eastern parts, where the principal auto repair shops and storages of old cars are concentrated.

$\mathrm{Ni}$ concentrations in soil ranged from 0.2 to $30.6 \mathrm{mg} \mathrm{kg}^{-1}$. The anomalies of Ni were located 
near the port areas, oil refinery, and in the new districts. In our previous studies, we proved that the nickel anomalies in the city are mainly associated with fuel combustion waste. Therefore, the most contrasting anomalies of the element are present in the vicinity of the refinery in the southeastern part of the city (Garcia et al 2010).

$\mathrm{Fe}$ concentrations in soil ranged from 1270 to $31019 \mathrm{mg} \mathrm{kg}^{-1}$. The distribution of $\mathrm{Fe}$ in the studied area seems well defined so that the highest concentrations are located in the eastern portion of the sampled region and the lowest in the west one. In the port regions, as well as the entire area of the embankment, including the refinery region; the industry region; the Historical Center; and in the landfill area in the northernmost portion of the peninsula are located the major anomalies of high concentrations ranging from 1500 to $31019 \mathrm{mg}$ $\mathrm{kg}^{-1}$. Iron like other metals is the marker of the intensity of technogenic processes on the surface of the soil. Therefore, in the central quarters of Rio Grande, where anthropogenesis has been active for more than 200 years, the iron concentration in soil is much higher than in the new eastern parts of the city (Fig. 4).

For the ecological-geochemical mapping of the cities Saet (1990) developed an integral coefficient of anomalous metals in the components of the urban environment. This coefficient was correlated with the incidence of the diseases of the population in the studied cities and was graded according to the degree of environmental hazard: $<16$ - background value; 16-32 - contamination; 32-64 - moderately dangerous pollution; 64-128 - dangerous pollution; 128-256 - very dangerous; > 256 unacceptable level of pollution requiring special measures for soil sanitation.
The anomaly coefficient $\mathrm{Zc}$, is the geochemical sum of the individual concentration coefficients of metals, Kc:

$$
\mathrm{Zc}=\sum_{n=1}^{n} \mathrm{Kc}-(\mathrm{n}-1), \text { for } \mathrm{Kc} \geq 1.5
$$

where:

$\mathrm{Kc}=\mathrm{Cx} / \mathrm{Bg}$,

$\mathrm{Cx}=$ metal concentration in the urban soil,

$\mathrm{Bg}=$ local background of the metal.

Anomalies of $\mathrm{Zc}$ that were revealed by principle of discount of the elements with minor value of Kc testified the centers of spreading of the contaminants in the city of Rio Grande (Fig.5). It can be seen on the map that the centers of the anomalies consisted of two metals, $\mathrm{Cu}$ and $\mathrm{Zn}$. This corresponds to the standard geochemical situation in most cities of the world, where these metals compose the basic paragenetic association of elements urban pollutants (Mirlean et al. 1992).

From the Zc map it follows that the centers of complex geochemical anomalies in the city correspond the areas of industrial activity and urban landfills. According to the level of $\mathrm{Zc}$ values in the city soils, it also follows that the greatest part of urban area has an unacceptable level of pollution where special remediation measures should be implemented.

Brazilian legislation does not support any complex assessment of the ecological situation in cities in terms of the content of chemical elements in urban soils. The actual norms in Brazil stipulate the limitation for the metals content in soils for various types of activity related to their disposition or use of soil cover (CONAMA, 2009).

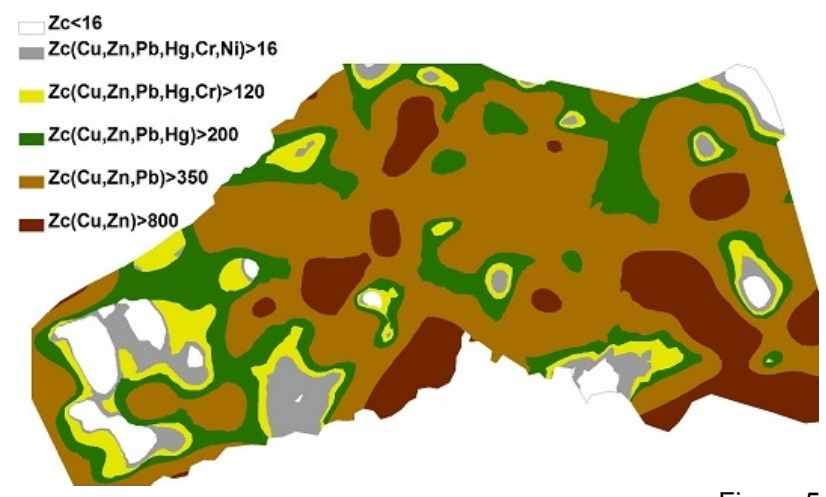

Figure 5

The map of the coefficient Zc in soil cover of the city of Rio Grande according to Gripp (2012).

Figure 6 shows the maps of metals distribution in surface soil of Rio Grande in accordance with the limits proposed by CONAMA. These limits include: i) the quality reference value $(\mathrm{QR})$, which is the concentration of a given metal that defines the natural quality of the soil, being determined 
based on statistical interpretation of physical and chemical analyzes of samples of different types of soils; ii) prevention value that is the concentration of limit value of a given metal in the soil, so that it is able to sustain main functions of the soil; iii) research value, which is the concentration of certain metal in the soil above which there are potential direct or indirect risks to human health
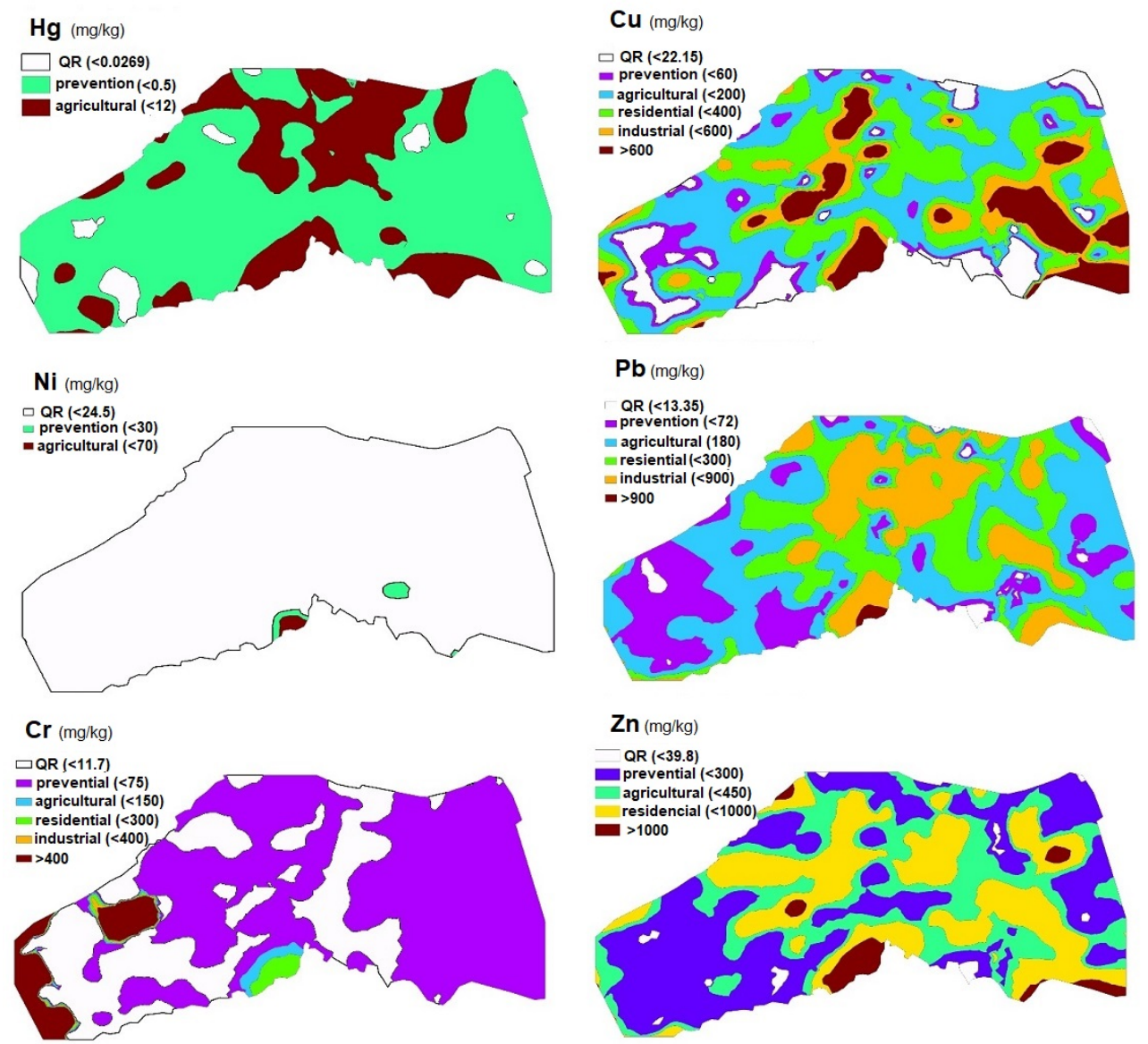

Figure 6

Metals distribution in surface soil, with concentration ranges according to Gripp (2012).

According to Article 13 of the CONAMA resolution № 420 (2009) the following soil quality classes are established according to the concentration of chemical substances: i) Class 1 , soils that have concentrations of chemical substances less than or equal to the value of RQ; ii) Class 2, soils that have concentrations of at least one chemical substance greater than the value of $\mathrm{RQ}$ and less or equal to the value of prevention; iii) Class 3, soils having concentrations of at least one chemical substance greater than the value of prevention and less than or equal to the value of the investigation; iv) Class 4 , soils that have concentrations of at least one chemical substance greater than the value of the investigation.

According to Article 20 of the legislation (CONAMA, 209) the following soil quality control and prevention procedures shall be observed: i) Class 1 does not require actions; ii) Class 2, may require an environmental assessment, including verification of the possibility of natural occurrence of the substance or the existence of sources of pollution, with indicative preventive control actions, when applicable, not necessarily involving investigation; iii) Class 3 , requires identification of the potential source of contamination, assessment of the natural occurrence of the substance, control of sources of contamination and monitoring ; iv) Class 4, requires the actions, established by this resolution, which deals with the guidelines for the management of contaminated areas.

The evaluation of the sampled area of the Rio Grande according to the legislation the soil studied are belonged to Class 4; It means that the principal territory of Rio Grande needs immediate management, which includes eliminating risks to human health and the environment and planning future of land uses . 


\section{CONCLUSION}

The distribution maps of the metals together with the statistical analysis were able to characterize the location of the anomalies as well as the basis for the suggestion of the probable sources of these pollutants to the urban soil.

Both the distribution maps of each metal and the index maps provided subsidies for the establishment of zones of environmental risk. These areas should be considered as investigation

\section{REFERENCES}

Alloway B.J. (Eds.) 1990. Heavy metals in soils. ed. Springer, London, 339 p.

Anderson R.H. \& Kravitz M.J. 2010. Evaluation of geochemical associations as a screening tool for identifying anthropogenic trace metal contamination. Environ. Monit. Assess., 167:631641.

ATSDR (Agency for Toxic Substances and Disease Registry). 1999. Toxicological Profile for Mercury. Atlanta, GA: U.S. Department of Health and Human Services, Public Health Service.

ATSDR (Agency for Toxic Substances and Disease Registry). 2004. Toxicological Profile for Copper. Atlanta, GA: U.S. Department of Health and Human Services, Public Health Service.

ATSDR (Agency for Toxic Substances and Disease Registry). 2005. Toxicological Profile for Zinc. Atlanta, GA: U.S. Department of Health and Human Services, Public Health Service.

Bastos C.A.B., Valente A.L.S., Botelho M.R. 2002. Aspectos do meio físico como condicionantes do uso e ocupação dos solos no município de Rio Grande/RS. In: ABGE, Congr. Bras. Geol. de Engen. Amb., $10^{\circ}$, Ouro Preto/MG,p.112.

Bastos C.A.B., Valente A.L.S., Tagliani C.R., Miranda T.C., Pinto W.S., Dias R.D. 2005. Mapeamento de unidades geotécnicas como subsídio a formação de um banco de dados geotécnicos georrefereciado para o município de Rio Grande/RS. In: ABGE, Congr. Bras. Geol. de Engen. Amb., $11^{\circ}$, Ouro Preto/MG,p.47.

Biondi C. M. 2010. Teores naturais de metais pesados nos solos de referência do estado de Pernambuco. Tese de Doutorado, Universidade Federal Rural de Pernambuco, $120 \mathrm{p}$.

Chen T.B., Zheng Y.M., Lei M., Huang Z.C., Wu H.T., Chen H., Fan K.K., Yu K., Wu X., Tian Q.Z. 2005. Assessment of heavy metal pollution in surface soils of urban parks in Beijing, China. Chemosphere: 60:542-551.

CONAMA, 2009. RESOLUÇÃO No 420, DE 28 DE DEZEMBRO DE 2009, DOU $\mathrm{n}^{\circ}$ 249, de 30/12/2009, p. 81-84.

Fadigas F.S., Sobrinho M.B., Mazur N., Anjos L.H.C., Freixo A. 2006. Proposição de valores de referência para a concentração natural de metais pesados em solos brasileiros. Ver. Bras. Eng. Agr. Amb., 10:699-705. priorities in order to protect the population and the surrounding environment. In the city of Rio Grande the list of these zones should include part of the central region of the city (Historic Center); the downtown neighborhood formed since the 70's of the 19th century; the regions of old industries; large part of the current industries; as well as man-made lands around the urban perimeter of the peninsula.

Felisberto R. 2009.Teor de mercúrio em solos do Rio Grande do Sul. Dissertação de Mestrado, Universidade Federal do Rio Grande do Sul, 120 p.

Garcia F.A.P., Mirlean N., Baisch P.R. 2010. Marcadores metálicos como avaliação do impacto crônico de emissões petroquímicas em zona urbana. Quím. Nov., 33:716 - 720.

Gripp M.L.R. 2012. Indicação geoquímica de desenvolvimento urbano-industrial em cidade portuária (Rio Grande-RS). Dissertação de mestrado, Universidade Federal do Rio Grande, 80 p.

Grünfeld K. 2005. Dealing with outliers and censored values in multi-element geochemical data - a visualization approach using XmdvTool. Appl. Geochem., 20: 341-352.

Hugen, C. 2010. Valores de referência para teores de $\mathrm{Cr}, \mathrm{Cu}, \mathrm{Ni}, \mathrm{Pb}$ e $\mathrm{Zn}$ em solos do estado de Santa Catarina. Dissertação do Mestrado, Universidade do Estado de Santa Catarina, Lages/SC,130p.

Jagtap M.N., Kulkarni M.V., Puranik P.R. 2010. Flux of Heavy Metals in soils irrigated with urban wastewaters. American-Eurasian J. Agric. \& Environ. Sci., 8: 487-493.

Kabata-Pendias A.\& Pendias H. 1992. Trace elements in soils and plants. CRC Press, USA, 215 p.

Kelly J., Thornton I., Simpson P.R. 1996. Urban geoche mistry: a study of the in fluence of anthropogenic activity on the heavy metal content of soils in traditionally industrial and non-industrial areas of Britain. Appl. Geochem., 11:363 - 370.

Kimpe C.R. \& Morel J.L. 2000. Urban soil management: a growing concern. Soil Sci., 165:3140.

Krishna, A.K. \& Govil, P.K. 2004. Heavy metal contamination of soil around Pali Industrial Area, Rajasthan, India. Environ. Geol.,47:38-44.

Krishna A.K. \& Govil P.K. 2005. Heavy metal distribution and contamination in soils of ThaneBelapur industrial development area, Mumbai, Western India. Environ. Geol., 47: 1054-1061.

Krishna A.K. \& Govil P.K. 2008. Assessment of heavy metal contamination in soils around Manali industrial area, Chennai, Southern India. Environ. Geol., 54:1465-147.

Li X., Huang C. 2007. Environment impact of heavy metals on urban soil in the vicinity of industrial 
area of Baoji city, P.R. China. Environ. Geol., 52:1631-1637.

Li X., Poon, C.S., Liu P.S. 2001 Heavy metal contamination of urban soils and street dusts in Hong Kong. Appl. Geochem., 16:1361-1368.

Lu S.G.\& Bai S.Q. 2010. Contamination and potential mobility assessment of heavy metals in urban soils of Hangzhou, China: relationship with different land uses. Environ. Earth Sci., 60:1481-1490.

Madrid L., Diaz-Barrientos E., Madrid F. 2002. Distribution of heavy metal contents of urban soils in parks of Seville. Chemosphere, 49: 1301-1308.

Martins S.F. 2006. Cidade do Rio Grande: Industrialização e urbanidade. FURG, Rio Grande, $245 \mathrm{p}$.

Mirlean N., Moraru K., Nastas G. 1992. Ecogeochemical atlas of the city Kishinev. Stiintsa, Kishinev, 180 p.

Mirlean N., Andrus V.E., Baisch P. 2003. Mercury pollution in sediments of Patos Lagoon estuary, Southern Brazil. Mar. Poll. Bull., 46:331-334.

Mirlean N., Baisch P., Machado, I., Shumillin E. 2008. Mercury contamination of soil as the result of long-term phosphate fertilizer production. Bull. Environ. Contam. Toxicol., 81: 305-308.

Mirlean N., Baraj B.,Niencheski L. F., Baisch P., Robinson D. 2001. The effect of accidental sulphuric acid leaking on metal distribution in estuarine sediment of Patos Lagoon. Mar. Poll. Bull., 42: 1114-1117.

Mirlean N., Calliari L., Baisch, P., Loitzenbauer E., Shumilin E. 2009. Urban activity and mercury contamination in estuarine and marine sediments (Southern Brazil). Environ. Monit. Assess., 157: 583-589.
Mirlean N., Robinson N., Kawashita D.K., Vignol L., Conceicao R., Chemale F. 2005. Identification of local sources of lead in atmospheric deposits in an urban area in Southern Brazil using stable lead isotope ratios. Atm. Environ., 39: 6204 - 6212.

Morton-Bermea O., Hernández-Álvarez E.,Lozano R., Guzmán-Morales J., Martínez G. 2010. Spatial Distribution of Heavy Metals in Top Soils Around the Industrial Facilities of Cromatos de México, Tultitlan Mexico. Bull. Environ. Contam. Toxicol., 85: 520-524.

Oliveira M.L., Melo S.B., França, M.M. 2010. Valores de referência de qualidade para metais pesados em solos no estado do Espírito Santo. R. Bras. Ci. Solo., 34:2041-2051.

Oliveira C. \& Mirlean N. 2006. Mercury in Coastal Reclamation Fills in Southernmost Brazil: Historical and Environmental Facets. J. Coast. Res., 22: p.1573-1581.

Paye H.S., Mello J.W.V., Abrahão W.A., Fernandes F.E.I., Dias L.C. 2006. Estudo multivariado de solos urbanos da cidade de Teresina. Quim. Nova, 29: 429-435.

Reimann C., Filzmoser P., Garrett R.G. 2005. Background and threshold: critical comparision of methods of determination. Sci. Tot. Envir., 346: 1-16.

Romic M. \& Romic, D. 2003 Heavy metals distribution in agricultural topsoils in urban area. Environ. Geol., 43: 795-805.

Saet Yu.E. 1990. Environmental Geochemistry. Nedra, Mocow, $336 \mathrm{p}$.

Salvatori E., Habiaga L.A.G., Thormann M.C. 1989. Crescimento horizontal da cidade do Rio Grande. Revista Brasileira de Geografia, 51: 27-72. 